\title{
Prevalence of piroplasms in small ruminants in North-West Tunisia and the first genetic characterisation of Babesia ovis in Africa
}

\author{
Mohamed Ridha Rjeibi ${ }^{1}$, Mohamed Gharbi ${ }^{1, *}$, Moez Mhadhbi ${ }^{1}$, Wiem Mabrouk ${ }^{1}$, Boutheïna Ayari ${ }^{1}$, \\ Ines Nasfi ${ }^{1}$, Mohamed Jedidi ${ }^{1}$, Limam Sassi ${ }^{1}$, Mourad Rekik ${ }^{2}$, and Mohamed Aziz Darghouth ${ }^{1}$ \\ 1 Laboratoire de Parasitologie, Université de la Manouba, École Nationale de Médecine Vétérinaire de Sidi Thabet, 2020 Sidi Thabet, \\ Tunisia \\ 2 International Centre for Agricultural Research in the Dry Areas (ICARDA), PO Box 950764, Amman 11195, Jordan
}

Received 17 January 2014, Accepted 7 May 2014, Published online 22 May 2014

\begin{abstract}
In this study, the prevalence of piroplasms in sheep and goats was assessed with Giemsa-stained blood smear examination, PCR and nested PCR-restriction fragment length polymorphism (RFLP) to identify Babesia and Theileria species, respectively, in 338 small ruminants (172 sheep and 166 goats) from three sites in North-West Tunisia during the 2011 summer season. The overall infection prevalence of piroplasms in Giemsa-stained blood smears was $3.2 \%$ (11/338), with a parasitaemia ranging from 0.01 to $0.05 \%$. PCR detected two species, namely Babesia ovis (in sheep and goats) and Theileria ovis (in sheep), with an overall prevalence of $16.3 \%$. The molecular prevalence of $B$. ovis was significantly higher in sheep than in goats $(17.4 \%$ and $9 \%$, respectively, $p=0.034)$. The same trend was observed for $T$. ovis in sheep and goats $(5.8 \%$ and $0 \%$, respectively, $p=0.004)$. Comparison of the partial sequences of the 18S rRNA gene revealed 100\% similarity amongst Babesia from sheep and goats. The single Theileria sequence in this study showed $100 \%$ similarity to $T$. ovis. A high similarity with all the blasted genotypes was reported for Theileria and Babesia sequences. This is the first molecular detection of $B$. ovis and genetic characterisation of small ruminants' piroplasms in Africa.
\end{abstract}

Key words: Small ruminants, Haemopathogen, Babesia ovis, Theileria ovis, PCR, Tunisia.

Résumé - Prévalence des piroplasmes chez les petits ruminants au nord-ouest de la Tunisie et première caractérisation génétique de Babesia ovis en Afrique. Dans cette étude, la prévalence des piroplasmes chez les ovins et les caprins a été évaluée par la technique de la coloration au Giemsa, la PCR et la PCR nichée et l'étude du polymorphisme des fragments de restriction (RFLP) pour identifier respectivement les espèces de Babesia et Theileria sur 338 petits ruminants (172 ovins et 166 caprins) provenant de trois sites au nord-ouest de la Tunisie pendant la saison estivale 2011. La prévalence globale de l'infection par les piroplasmes par la technique de la coloration au Giemsa était de 3,2\% (11/338) avec une parasitémie variant entre 0,01 et $0,05 \%$. La PCR a détecté deux espèces, Babesia ovis (ovins et caprins) et Theileria ovis (ovins), avec une prévalence globale de 16,3\%. La prévalence moléculaire de l'infection par $B$. ovis était significativement plus élevée chez les ovins que les caprins (respectivement $17,4 \%$ et $9 \%, p=0,034$ ). La même tendance a été observée pour $T$. ovis chez les ovins et les caprins (respectivement $5,8 \%$ et $0 \%, p=0,004$ ). La comparaison des séquences partielles du gène $18 \mathrm{~S} \mathrm{ARNr}$ a révélé une homologie de $100 \%$ entre les séquences de Babesia des ovins et des caprins. La seule séquence de Theileria de cette étude a montré une homologie de $100 \%$ avec T. ovis. Une grande homologie avec les génotypes étudiés par BLAST a été retrouvée pour les séquences de Theileria et de Babesia. Ceci est la première détection moléculaire de $B$. ovis et la première caractérisation génétique des piroplasmes de petits ruminants en Afrique.

\footnotetext{
*Corresponding author: gharbim2000@yahoo.fr
}

This is an Open Access article distributed under the terms of the Creative Commons Attribution License (http://creativecommons.org/licenses/by/4.0), which permits unrestricted use, distribution, and reproduction in any medium, provided the original work is properly cited. 


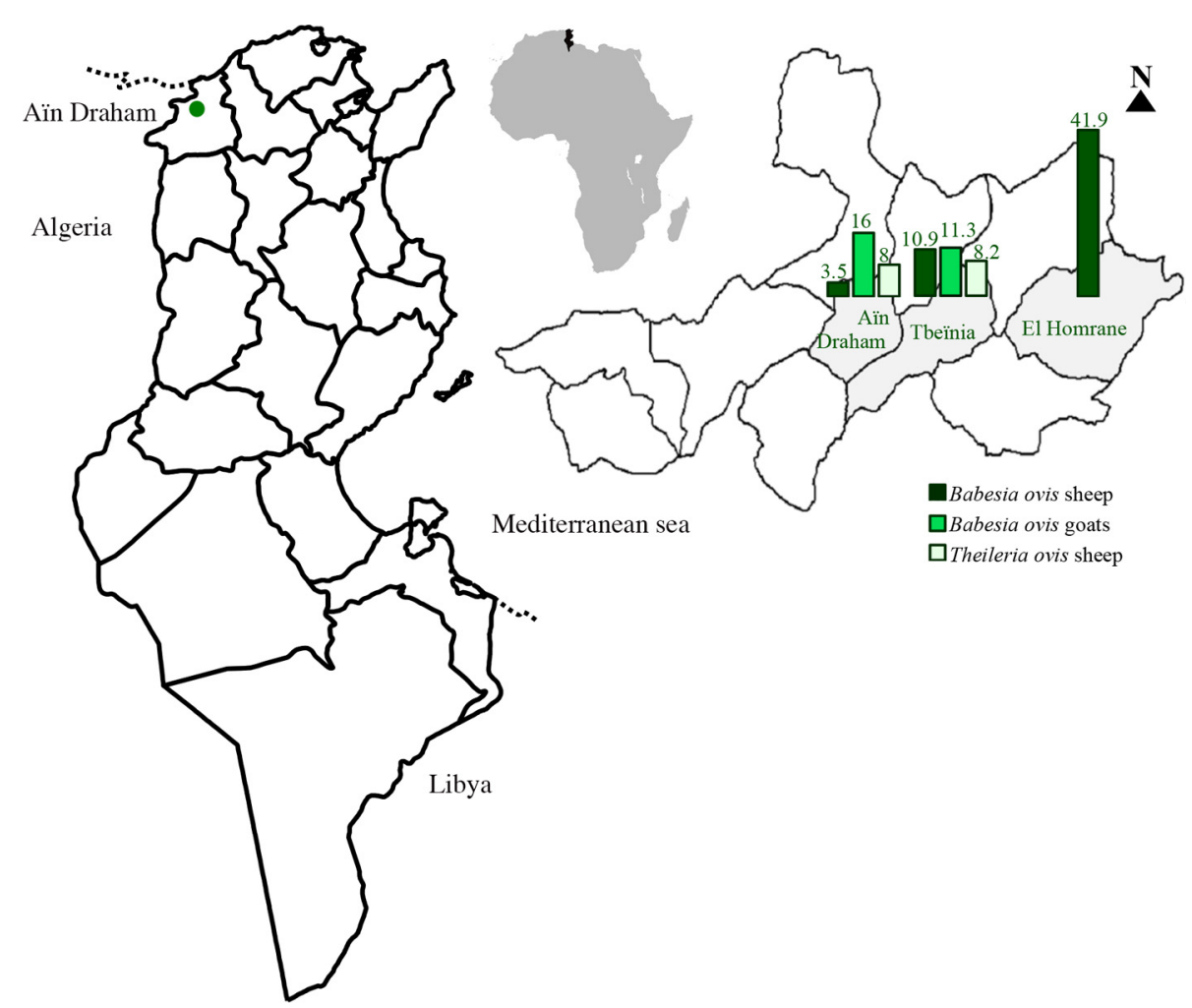

Figure 1. Sheep and goat PCR infection prevalence of Babesia ovis and Theileria ovis in the Aïn Draham locality (North-West Tunisia).

\section{Introduction}

There are over 1.07 billion sheep in the world; $27 \%$ of them are located in Africa [15]. Sheep are amongst the major economically important livestock in Tunisia, with a total population of 6.5 million sheep; they play an important role in the livelihood of resource-poor farmers. The goat population is lower; it was estimated at 1.5 million head in Tunisia [28].

In North Africa, small ruminants are exposed to several health problems, such as abortive diseases (brucellosis, border disease, toxoplasmosis, salmonellosis, campylobacteriosis) [19], and gastrointestinal and respiratory helminths [2-4]. Moreover, the stock owners face extreme climatic conditions with a very long dry period, leading to dramatic decreases in food resources' quality and quantity. Several inputs are expensive such as diesel oil, imported concentrate and drugs, leading to a weakening of the financial assets of the small-scale farmers. In addition, climate change, in particular global warming, is further exacerbating the fragile environment where the animals are thriving. Many endemic pathogens are neglected by stock owners since they do not cause significant symptoms or financial losses. Some of them are highly prevalent in animal populations; they cause small but persistent losses, and when cumulated all together they generate huge losses to the farmers. Piroplasms are small ruminants' neglected infections. Several species of Babesia (B. ovis, Babesia motasi, Babesia crassa and Babesia sp. Xinjiang) have been described in small ruminants; amongst them, $B$. ovis and $B$. motasi are believed to be causative agents of babesiosis $[25,30,35,41]$.
Recently, two studies were carried out in South Africa and northern Ethiopia; they showed the presence of several species of Theileria in domestic small ruminants. In northern Ethiopia, two Theileria species were recently reported in small ruminants, namely T. ovis and Theileria separata, whereas no Babesia spp. was found [18]. In South Africa, four piroplasm species were found in sheep, namely T. ovis, T. separata, Theileria bicornis and Theileria sp. (sable) [8].

Screening piroplasm-infected small ruminants can be carried out either by blood smear examination, which is a rapid, cheap and easy but not sensitive technique, or by PCR, which is sensitive but expensive. The combination in series of these two techniques can represent a powerful tool for screening animals infected with piroplasms.

We describe herein an epidemiological survey carried out on small ruminants' piroplasm infection in a humid region of Tunisia where production systems are low-input and extensive. This epidemiological study was followed by a genetic comparison of the Tunisian small ruminant piroplasms with others from different regions in the world.

\section{Materials and methods}

\section{Study area}

The present study was carried out in three sites of Ain Draham (district of Jendouba, North-West Tunisia; Fig. 1). This region has an altitude ranging between 305 and $680 \mathrm{~m}$; it is 
Table 1. Primers used for detection by PCR of Babesia ovis and Theileria spp. from sheep and goats in this study.

\begin{tabular}{|c|c|c|c|c|c|c|}
\hline $\begin{array}{l}\text { Primer } \\
\text { specificity }\end{array}$ & $\begin{array}{l}\text { Target } \\
\text { Gene }\end{array}$ & Name & Type & Primers $5^{\prime}-3^{\prime}$ & $\begin{array}{l}\text { Product size } \\
\text { (bp) }\end{array}$ & Reference \\
\hline$\overline{C a t c h-a l l}$ & $18 S$ rRNA & $\begin{array}{l}\text { RLB-F } \\
\text { RLB-R }\end{array}$ & $\begin{array}{l}\text { Forward primer } \\
\text { Reverse primer }\end{array}$ & $\begin{array}{l}\text { GAGGTAGTGACAAGAAATAACAATA } \\
\text { TCTTCGATCCCCTAACTTTC }\end{array}$ & $460-520$ & Gubbels et al. [20] \\
\hline B. ovis & $18 S$ rRNA & $\begin{array}{l}\text { Bbo-F } \\
\text { Bbo-R }\end{array}$ & $\begin{array}{l}\text { Forward primer } \\
\text { Reverse primer }\end{array}$ & $\begin{array}{l}\text { TGGGCAGGACCTTGGTTCTTCT } \\
\text { CCGCGTAGCGCCGGCTAAATA }\end{array}$ & 549 & Aktas et al. [5] \\
\hline Theileria spp. & $18 S$ rRNA & $\begin{array}{l}\text { Thei F1 } \\
\text { Thei R1 }\end{array}$ & $\begin{array}{l}\text { Forward primer } \\
\text { Reverse primer }\end{array}$ & $\begin{array}{l}\text { AACCTGGTTGATCCTGCCAG } \\
\text { AAACCTTGTTACGACTTCTC }\end{array}$ & 1700 & Heidarpour Bami et al. [21] \\
\hline & $18 S$ rRNA & $\begin{array}{l}\text { Thei F2 } \\
\text { Thei R2 }\end{array}$ & $\begin{array}{l}\text { Forward primer } \\
\text { Reverse primer }\end{array}$ & $\begin{array}{l}\text { TGATGTTCGTTTYTACATGG } \\
\text { CTAGGCATTCCTCGTTCACG }\end{array}$ & $1417-1426$ & Heidarpour Bami et al. [21] \\
\hline
\end{tabular}

Table 2. Theileria ovis and Babesia ovis infection prevalence and intensity in sheep and goats by Giemsa-stained blood smears and PCR in Aïn Draham, North-West Tunisia.

\begin{tabular}{|c|c|c|c|c|c|c|}
\hline Species & Epidemiological indicator & Technique & Sheep & Goats & $95 \% \mathrm{CI}^{\mathrm{c}}$ & $p$ value \\
\hline \multirow[t]{3}{*}{ B. ovis } & \multirow{2}{*}{$\begin{array}{l}\text { Infection prevalence }=100 \times(\text { number of positive blood } \\
\text { samples/number of examined blood samples })(\%)\end{array}$} & $\mathrm{MO}^{\mathrm{a}}$ & $5 / 172(2.9)$ & $4 / 166(2.4)$ & {$[0.28 ; 5.48]$} & 0.77 \\
\hline & & PCR & $30 / 172(17.4)$ & $15 / 166(9.04)$ & & $0.022 *$ \\
\hline & $\begin{array}{l}\text { Infection intensity }=100 \times(\text { number of positive red blood } \\
\text { cells/number of examined red blood cells })\end{array}$ & MO & 0.015 & 0.031 & {$[0 ; 0.004]$} & 0.102 \\
\hline \multirow[t]{3}{*}{ T. ovis } & \multirow{2}{*}{$\begin{array}{l}\text { Infection prevalence }=100 \times(\text { number of positive blood } \\
\text { samples/number of examined blood samples })(\%)\end{array}$} & MO & $2 / 172(1.16)$ & $0 / 166$ & $\mathrm{NA}^{\mathrm{b}}$ & 0.16 \\
\hline & & $\mathrm{PC}$ & $10 / 172(5.81)$ & $0 / 166(0)$ & NA & $0.001 *$ \\
\hline & $\begin{array}{l}\text { Infection intensity }=100 \times(\text { number of positive red blood } \\
\text { cells/number of examined red blood cells })(\%)\end{array}$ & MO & 0.022 & 0 & {$[0 ; 0.005]$} & 0.105 \\
\hline
\end{tabular}

${ }^{\text {a }} \mathrm{MO}$ - Microscopy observation.

${ }^{\mathrm{b}} \mathrm{NA}$ - not applicable.

${ }^{c}$ CI $-95 \%$ Confidence interval.

${ }^{*}$ Significant test.

humid, with a mean annual rainfall of $1300 \mathrm{~mm}$, and dry during the summer season. The mean minimal temperature is $8.1^{\circ} \mathrm{C}$ in January, whilst the mean maximum temperature is $30{ }^{\circ} \mathrm{C}$ in August (National Institute of Meteorology, Tunisia).

\section{Animals and samples}

During the 2011 summer season (June and July), clinically healthy sheep $(n=172)$ and goats $(n=166)$ were included in the survey from 31 randomly selected small ruminant flocks. The sheep belong to two breeds, namely Queue Fine de l'Ouest (60.4\%) and Barbarine sheep (39.5\%). The goats were of the local population $(86.7 \%)$ and Damascus genotypes $(13.2 \%)$. A full description of the animals' breeds was reported by Rekik et al. [33]. The animals graze daily on spontaneous vegetation. During summer, it is occasionally supplemented by bran, barley and concentrate. Based on dentition, animals were ranked into three age groups: less than one year, between one and two years and more than two years. All the animals included in the current survey were examined for ticks, which were collected in labelled tubes containing 70\% ethanol and identified under a stereomicroscope based on the key of Walker et al. [42]. Three tick infestation indicators were determined:

Infestation prevalence $(\%)=100 \times($ number of infested animals/total number of animals).

Infestation intensity $=$ number of ticks/number of infested animals.

Abundance $=$ number of ticks/total number of animals.
Blood samples were collected in EDTA tubes from the jugular vein of each animal. Giemsa-stained blood smears were examined under a microscope with immersion oil at $1000 \times$ magnification for the presence of piroplasms. For each slide, 50 microscopic fields were examined.

\section{Polymerase chain reaction and PCR-RFLP}

DNA was extracted from $300 \mu \mathrm{L}$ of blood using the Wizard $^{\circledR}$ Genomic DNA purification kit (Promega, Madison, USA) according to the manufacturer's instructions; it was stored at $-20{ }^{\circ} \mathrm{C}$ until used. Catch-all primers (RLB-F and RLB-R) which detect both Theileria spp. and Babesia spp. piroplasms were used [20] (Table 1). Forty PCR cycles were performed with a thermocycler (ESCO Swift MaxPro) in a total reaction volume of $25 \mu \mathrm{L}$. Five microlitres of each positive sample were amplified by 35 PCR cycles using primers detecting B. ovis (Bbo-F and Bbo-R) [5] (Table 1). A nested PCR detecting specific Theileria DNA of the $18 \mathrm{~S}$ ss rRNA gene was performed. The primary PCR consisted of 25 cycles realised with $20 \mathrm{pg}$ of outer primers (Thei F1 and Thei R1) in $30 \mu \mathrm{L}$ volume. One microlitre of each PCR product was used as a template in a 30-cycle nested PCR in the same mixture as the primary PCR with two different primers (Thei F2 and Thei R2) [21] (Table 1).

In order to differentiate Theileria annulata, Theileria lestoquardi and $T$. ovis, restriction fragment length polymorphism (RFLP) was performed with HpaII and HaeII restriction enzymes (Fermentase) [21]. Ten microlitres of the PCR product 
Table 3. RFLP pattern of different Theileria species after HpaII and HaeII digestion (Heidarpour Bami et al. [21]).

\begin{tabular}{lcc}
\hline Theileria species & Digestion products obtained by HpaII (bp) & Digestion products obtained by HaeII (bp) \\
\hline Theileria ovis & $856,326,204$ and 39 & 1131 and 295 \\
Theileria annulata & $1178,106,94$ and 39 & No digestion \\
Theileria lestoquardi & $900,278,106,94$ and 39 & No digestion \\
\hline
\end{tabular}

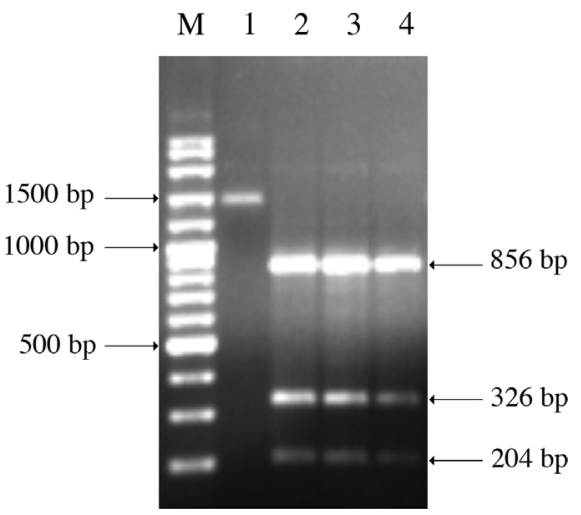

Figure 2. Digestion pattern of nested Theileria spp. 18S rRNA gene PCR products by HpaII. Lane M: 100 bp ladder; lane 1: Theileria spp. DNA; lanes 2-4: Theileria ovis (856, 326 and 204 bp).

were mixed with $2 \mu \mathrm{L}$ of $10 \times$ enzyme buffer and $10 \mathrm{U}$ of the restriction enzyme, then incubated at $37^{\circ} \mathrm{C}$ for $2 \mathrm{~h}$ (Table 3).

\section{DNA sequencing and phylogenetic analysis}

Three selected PCR products were purified with the Wizard SV gel and PCR clean-up system (Promega, Madison, USA) according to the manufacturer's instructions. The products were sequenced in both directions with the same primers as for PCR. A conventional Big Dye Terminator cycle sequencing ready reaction kit (Applied Biosystems, Foster City, CA, USA) with an ABI3730XL automated DNA sequence was used. The chromatograms were evaluated with ChromasPro software (version 1.7.4). The MEGA 5.1 program was used to perform multiple sequence alignments [39]. The sequences were compared with the GenBank database by a nucleotide sequence homology search carried out at the network server of the National Centre for Biotechnology Information (NCBI) using BLAST. The sequence of the $18 \mathrm{~S}$ ssu rRNA genes of $B$. ovis from sheep (BOTNSHAD01) and goats (BOTNGTAD01) and T. ovis from sheep (TOTNSHAD01) identified in the present survey were deposited in GenBank under Accession Nos. KF723611, KF723612 and KF723613, respectively. Phylogenetic trees were constructed by the neighbour-joining method [34]. The percentage of replicate trees in which the associated taxa clustered together in the bootstrap test (1100 replicates) was shown next to the branches [16]. The evolutionary distances were computed using the Tamura-Nei method [38] and are in the units of the number of base differences per site. Evolutionary analyses were conducted with MEGA 5.1 software (Fig. 3).

\section{Statistical analyses}

The infection prevalence percentages were compared using Epi Info 6 [13]. In order to consider any confusion factor, a chisquare Mantel-Haenszel test was performed. A probability less than 0.05 was used as a threshold for statistical significance [37]. The concordance between PCR and blood smears was estimated with a kappa test [40].

\section{Results}

Only 24 and 15 ticks all belonging to Rhipicephalus turanicus were collected from sheep and goats, respectively. The overall prevalence of tick infestation was $8.87 \%(30 / 338)$, the intensity (1.3) and the abundance (0.11). There were no statistically significant differences in piroplasm prevalence in tickinfested and noninfested animals $(p>0.05)$. Our study showed that tick infestation prevalence was significantly higher in Damascus goats than local ones $(p<0.05)$. This difference was not reported in sheep $(p>0.05)$. The overall infection prevalence of piroplasms was $3.25 \%(11 / 338)$ and the overall mean parasitaemia was $0.011 \%$ (range: $0.01 \%-0.05 \%$ ).

All positive blood smears were positive by nested PCR. The enzymatic digestion profile by HpaII showed that all the PCR products belong to T. ovis species (10/338) (Fig. 2). A total number of nine and two animals were exclusively infected by Babesia spp. and Theileria spp. in blood smears, respectively; no animals were coinfected by both parasites (Table 2). Fifty-five samples were positive for T. ovis and B. ovis by PCR. There is a moderate concordance between PCR and blood smears for $T$. ovis and $B$. ovis in sheep and B. ovis in goats ( $\kappa=0.32,0.25$ and 0.4 , respectively).

The molecular prevalence of $B$. ovis and $T$. ovis was higher in sheep than in goats ( $p=0.034$ and $p=0.004$, respectively). There was no difference in the molecular prevalence of $B$. ovis and $T$. ovis for different age categories. The B. ovis infection rate in Barbarine sheep was higher than in Queue Fine de l'Ouest sheep $(p<0.05)$, whilst it was significantly higher in Damascus than local goats $(p<0.05)$, and no difference was detected in $T$. ovis prevalence in both hosts $(p>0.05)$ (Table 4). Infection prevalence of $B$. ovis varies in localities for sheep and goats $(p<0.05)$, whilst no difference was recorded in T. ovis $(p>0.05)$ (Table 4$)$. The infection rate by $T$. ovis was significantly higher in females than in males $(p<0.05)$.

One $B$. ovis amplicon from sheep, another from goats and one Theileria from sheep were randomly chosen for genetic analysis. The comparison of the $18 \mathrm{~S}$ ssu rRNA B. ovis sequence (509 bp length) revealed 100\% homology between the two Babesia genotypes. The two amplicons from sheep 


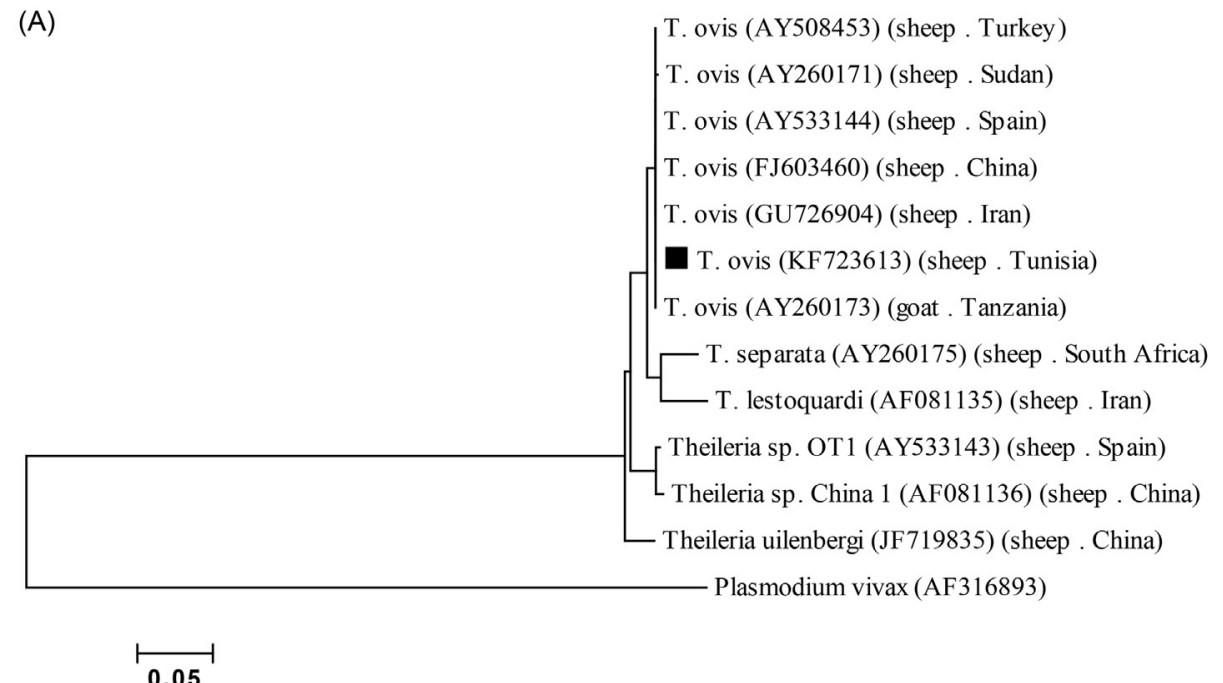

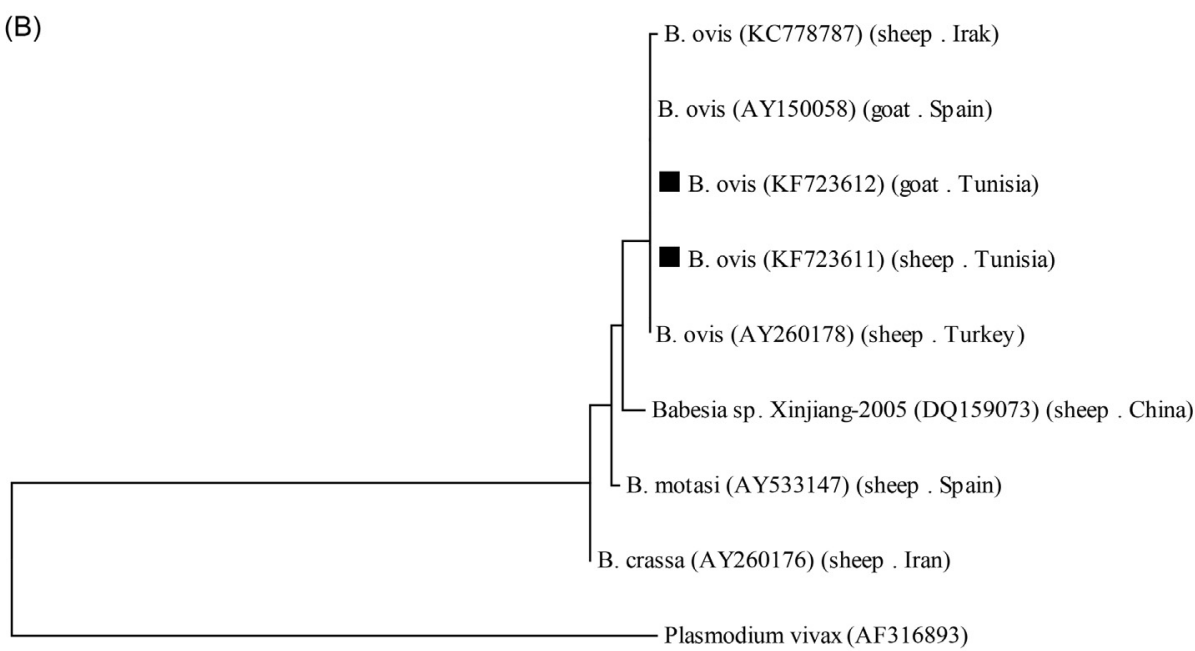

$$
\longmapsto
$$

Figure 3. The tree was constructed using the neighbour-joining method [34]. The percentage of replicate trees in which the associated taxa clustered together in the bootstrap test (1100 replicates) is shown next to the branches [16]. The evolutionary distances were computed using the Tamura-Nei method [38] and are in the units of the number of base differences per site. Evolutionary analyses were conducted in MEGA5.1 [39]. GenBank accession numbers are given in parentheses. Species described in this study are indicated with a black square. (A) Partial sequence 18S rRNA gene phylogenetic tree of the species identified in this survey and the main small ruminants' Theileria species. (B) Partial sequence 18S rRNA gene phylogenetic tree of the species identified in this survey and the main small ruminants' Babesia species.

and goats (509 bp) shared 100, 99.8, 99.6 and 99.2\% homology with the recently reported sequences for the $18 \mathrm{~S}$ ssu rRNA gene of B. ovis from Spain (AY150058), Turkey (AY260178), Iraq (KC778787) and eastern Turkey (AY998124), respectively (Fig. 3B). The Theileria amplicon (742 bp length) showed 100, 99.8, 99.8, 99.8, 99.8 and 99.7\% homology with $T$. ovis from Iran (GU726904), China (FJ603460), Spain (AY533144), Tanzania (AY260173), Turkey (AY508458) and Sudan (AY260171), respectively (Fig. 3A).

A phylogenetic tree of Theileria and Babesia was constructed from the 18S rRNA gene sequences of our amplicons and those available in GenBank. The first phylogenetic tree consists of all Theileria species; the $T$. ovis sequence (742 bp) described herein forms a well-supported clade with all the studied $T$. ovis, whereas the other Theileria species belonged to different clades such as T. lestoquardi and T. separata (Fig. 3A). Concerning Babesia sequences (509 bp), the phylogenetic analysis showed evidence of four monophyletic clades, one consisting of $B$. ovis and the others B. crassa, $B$. motasi and Babesia sp. Xinjiang-2005, with well-supported separation amongst them. The two $B$. ovis sequences described in this study formed a well-supported clade with the other $B$. ovis sequences clearly distinct from B. motasi, B. crassa and Babesia sp. Xinjiang-2005 (Fig. 3B). 
Table 4. Association between the presence of sheep and goat piroplasms and different parameters based on PCR.

\begin{tabular}{|c|c|c|c|c|c|c|}
\hline \multirow[t]{2}{*}{ Species } & \multirow[t]{2}{*}{ Parameter } & & \multicolumn{2}{|c|}{ Babesia ovis } & \multicolumn{2}{|c|}{ Theileria ovis } \\
\hline & & & Positive/examined (\%) & OR $[95 \% \mathrm{CI}]$ & Positive/examined (\%) & OR $[95 \% \mathrm{CI}]$ \\
\hline \multirow[t]{10}{*}{ Sheep } & \multirow[t]{2}{*}{ Gender } & Female & $23 / 126(18.2)$ & $0.9[0.27 ; 2.96]$ & $10 / 126(7.9)^{*}$ & $\mathrm{NA}^{\mathrm{a}}$ \\
\hline & & Male & $7 / 46(15.2)$ & & $0 / 46(0)$ & \\
\hline & \multirow{2}{*}{ Breed } & Barbarine & $18 / 68(26.5)$ & $2.76[1.15 ; 6.61]^{*}$ & $5 / 68(7.3)$ & $1.57[0.38 ; 6.58]$ \\
\hline & & $\mathrm{QFO}^{\mathrm{b}}$ & $12 / 104(11.5)$ & & $5 / 104(4.8)$ & \\
\hline & \multirow[t]{3}{*}{ Age group } & $<1$ year & $4 / 21(19)$ & $3.37[0.55 ; 21.81]$ & $3 / 21(14.3)$ & $3.67[0.44 ; 34.93]$ \\
\hline & & 1 to 2 years & $3 / 46(6.5)$ & & $2 / 46(4.3)$ & \\
\hline & & $>2$ years & 23/105 (21.9) & $4.02[1.06 ; 17.88]^{*}$ & $5 / 105(4.8)$ & $1.1[0.18 ; 8.55]$ \\
\hline & \multirow[t]{3}{*}{ Locality } & Aïn Draham & 1/28 (3.6) & & $2 / 28(7.1)$ & NA \\
\hline & & Tbeïnia & 11/101 (10.9) & $3.3[0.41 ; 71.41]$ & 8/101 (7.9) & \\
\hline & & El Homrane & $18 / 43(41.9)$ & $19.44[2.4 ; 419.3]^{* *}$ & $0 / 43(0)$ & \\
\hline \multirow[t]{10}{*}{ Goats } & \multirow[t]{2}{*}{ Gender } & Male & 4/40 (10) & $1.39[0.29 ; 6.96]$ & $0 / 40(0)$ & NA \\
\hline & & Female & $11 / 126(8.7)$ & & $0 / 126(0)$ & \\
\hline & \multirow[t]{2}{*}{ Breed } & Damascus & $6 / 22(27.3)$ & $5.63[1.53 ; 20.48]^{*}$ & $0 / 22(0)$ & NA \\
\hline & & Local & $9 / 144(6.2)$ & & $0 / 144(0)$ & \\
\hline & \multirow[t]{3}{*}{ Age group } & $<1$ year & $0 / 18(0)$ & NA & $0 / 18(0)$ & NA \\
\hline & & 1 to 2 years & 6/42 (14.3) & & $0 / 42(0)$ & \\
\hline & & $>2$ years & $9 / 106(8.5)$ & & $0 / 106(0)$ & \\
\hline & \multirow[t]{3}{*}{ Locality } & Aïn Draham & $4 / 25(16 \%)^{*}$ & NA & $0 / 25(0)$ & NA \\
\hline & & Tbeïnia & $11 / 97(11.3 \%)$ & & 0/97 (0) & \\
\hline & & El Homrane & $0 / 44(0 \%)$ & & $0 / 44(0)$ & \\
\hline \multirow[t]{8}{*}{ Overall } & \multirow[t]{2}{*}{ Gender } & Female & $34 / 252(13.5 \%)$ & $0.67[0.26 ; 1.6]$ & $10 / 252(4)$ & NA \\
\hline & & Male & $11 / 86(12.8 \%)$ & & $0 / 86(0)$ & \\
\hline & \multirow[t]{3}{*}{ Age group } & $<1$ year & $4 / 39(10.2 \%)$ & & $3 / 39(7.7)$ & $3.58[0.46 ; 32.27]$ \\
\hline & & 1 to 2 years & $9 / 88(10.2 \%)$ & $1[0.26 ; 4.16]$ & $2 / 88(2.3)$ & \\
\hline & & $>2$ years & $32 / 211(15.2 \%)$ & $1.56[0.59 ; 5.58]$ & $5 / 211(2.4)$ & $1.04[0.18 ; 7.93]$ \\
\hline & \multirow[t]{3}{*}{ Locality } & Aïn Draham & $5 / 53(9.4 \%)$ & & $2 / 53(3.8)$ & NA \\
\hline & & Tbeïnia & $22 / 198(11.1 \%)$ & $1.2[0.4 ; 3.83]$ & $8 / 198(4)$ & \\
\hline & & El Homrane & 18/87 (20.7\%) & $2.5[0.8 ; 8.32]$ & $0 / 87(0)$ & \\
\hline
\end{tabular}

${ }^{*} 0.001 \leq p<0.05$.

${ }^{* *} p<0.001$.

${ }^{\mathrm{a}} \mathrm{NA}$ - not applicable.

${ }^{\mathrm{b}}$ Queue Fine de l'Ouest.

\section{Discussion}

Babesiosis is a tick-borne disease causing low but persistent losses with high prevalence of carrier state infection in small ruminants, thereby resulting in high economic losses in several tropical and subtropical regions [1, 27, 41]. Our survey samplings were performed during the summer season, since both T. ovis and $B$. ovis are transmitted by Rhipicephalus bursa and $R$. turanicus, which have a vernal activity $[9,12]$.

The diagnosis of piroplasm infections is mainly performed by microscopic examination of Giemsa-stained blood smears. However, this method has a low sensitivity and requires expertise because these parasites have similar morphology and therefore, different species may be confused. The detection of Babesia infection in carrier animals by DNA amplification is a powerful tool for epidemiological investigations, since it is more sensitive and specific than Giemsa-stained blood smears $[7,11]$.

In the present study, the molecular prevalence of $B$. ovis in small ruminants was significantly higher than Giemsa-stained blood smear examination $(2.66 \%)$; the latter technique does not detect carrier animals with very low parasitaemia. This result is consistent with previous reports about B. ovis [6] and Babesia spp. [30] in Turkey and Iran, respectively. The overall parasitaemia ranged from $0.01 \%$ to $0.05 \%$. In similar studies, other findings showed that $B$. ovis-infected sheep had low parasitaemia $(0.01 \%-0.1 \%)[29,32]$.

Babesia ovis molecular prevalence was significantly higher in sheep $(30 / 172,17.44 \%)$ than goats $(15 / 166,9.04 \%)$ $(p=0.022)$. It was stated that $B$. ovis induces symptoms more frequently in sheep than goats [17]. In Turkey, sheep B. ovis infection prevalence was higher than in goats (10.66 and 1\%, respectively) [6]; the same trend was observed in Pakistan (50\% and 24\%, respectively) [23], contrary to another survey carried out in Turkey, where no significant difference was reported between sheep and goats' infection prevalence $(2.9 \%$ and $2 \%$, respectively) [22].

The highest $B$. ovis infection rate was observed in Barbarine sheep compared with the Queue Fine de l'Ouest breed $(26.5 \%$ and $11.5 \%$, respectively) $(p<0.05)$ but in goats, the infection prevalence was higher in crossbred animals compared with animals of the local population $(27.3 \%$ and $6.2 \%$, respectively) $(p<0.05)$. For sheep, this can be explained by the fact that animals of the Barbarine breed are not in their natural 
environment, which is the steppe of dry land in central Tunisia. In goats, the results may refer to a higher genetic resistance of local breeds to piroplasms in comparison with exotic breeds.

No significant association was observed between the animals' ages and $B$. ovis infection prevalence, confirming the presence of an endemic stability state, as reported by others $[6,31,32]$. This is contrary to the findings in Pakistan [23], where the prevalence in animals aged less than one year was higher. No difference was detected in B. ovis prevalence between males and females $(p>0.05)$; our results are contradictory to other surveys reporting that the prevalence in male sheep and goats was higher than females [23]. The association between tick burdens and piroplasm prevalence was statistically not significant $(p>0.05)$; our results do not coincide with other findings that reported the presence of a positive correlation between tick burden and infection prevalence [5, 14, 24]. The two B. ovis sequences (from sheep and goat) had $100 \%$ similarity for the 18S rRNA gene. They were also identical to the Spanish sequence (AY150058) [10] and had a high genetic homology with all $B$. ovis deposited sequences in GenBank, namely eastern Turkey (99.2\%) (AY998123), Iraq (99.6\%) (KC778787) and Central Turkey (99.8\%) (AY260178) [36]. Contrary to reports in Tunisia [26], Pakistan [24] and Ethiopia [18], which detected T. ovis in sheep and goats, this species was only present in sheep. Only females were infected by $T$. ovis; this result disagrees with others who reported the presence of the parasite in both sexes [24]. Unlike other surveys, we did not find any significant variation between different ages and breed groups [26].

Theileria ovis from sheep showed lower genetic diversity. The Iranian sequence (GU726904) [43] had a 100\% homology with our sequences; all the $T$. ovis sequences from three continents (Africa, Europe and Asia) were clustered together in a big clade clearly distinct from Theileria sp. China (AF081136) and T. lestoquardi (AF081136), which are pathogenic for small ruminants. As far as could be ascertained from accessible published works, there are no published reports on small ruminants' B. ovis infection in Africa. Further studies are needed to improve our knowledge on small ruminants' ticks and tickborne pathogen epidemiology in North Africa and to explore the role of these piroplasms in sheep and goat pathology.

Acknowledgements. This study was financially supported by the "Laboratoire d'épidémiologie des infections enzootiques des herbivores en Tunisie : application à la lutte » (Ministère de l'enseignement supérieur et de la recherche scientifique, Tunisia), an EU-funded Pirovac with the No. 245145 and the Deutsche Forschungsgemeinschaft project "Molecular epidemiology network for promotion and support of delivery of live vaccines against Theileria parva and Theileria annulata infection in eastern and northern Africa" (AH 41/7-1). The authors thank Dr. Mourad Ben Said, Mr. Bechir Guesmi, Mr. Mokhtar Dhibi and Mr. Taoufik Lahmar for their support, and all the sheep and goat farmers who agreed to let us handle their animals.

\section{References}

1. Ahmed J, Yin H, Schnittger L, Jongejan F. 2002. Ticks and tickborne diseases in Asia with special emphasis on China. Parasitology Research, 88, 51-55.
2. Akkari H, Gharbi M, Darghouth MA. 2011. Infestation of tracer lambs by Fasciola hepatica in Tunisia: determining periods for strategic anthelmintic treatments. Revue Scientifique et Technique de l'Office International des Épizooties, 30, 917-929.

3. Akkari H, Gharbi M, Darghouth MA. 2012. Dynamics of infestation of tracers lambs by gastrointestinal helminths under a traditional management system in the North of Tunisia. Parasite, 19, 407-415.

4. Akkari H, Jebali J, Gharbi M, Mhadhbi M, Awadi S, Darghouth MA. 2013. Epidemiological study of sympatric Haemonchus species and genetic characterization of Haemonchus contortus in domestic ruminants in Tunisia. Veterinary Parasitology, 193, $118-125$.

5. Aktas M, Altay K, Dumanli N. 2005. Development of a polymerase chain reaction method for diagnosis of Babesia ovis infection in sheep and goats. Veterinary Parasitology, 133, 277-281.

6. Aktas M, Altay K, Dumanli N. 2007. Determination of prevalence and risk factors for infection with Babesia ovis in small ruminants from Turkey by polymerase chain reaction. Parasitology Research, 100, 797-802.

7. Aktas M, Dumanli N, Cetinkaya B, Cakmak A. 2002. Field evaluation of PCR in detecting Theileria annulata infection in cattle in the east of Turkey. Veterinary Record, 150, 548-549.

8. Berggoetz M, Schmid M, Ston D, Wyss V, Chevillon C, Pretorius A-M, Gern L. 2014. Tick-borne pathogens in the blood of wild and domestic ungulates in South Africa: interplay of game and livestock. Ticks and Tick-borne Diseases, 5, $166-175$.

9. Bouattour A. 1999. Distribution des principales tiques ixodidea du bétail en Tunisie. Premières journées vétérinaires africaines, 31 mai-2 juin 1987, Hammamet, Tunisia, 161-182.

10. Criado-Fomelio A, Martinez-Marcos A, Buling-Saraña A, Barba-Carretero JC. 2003. Molecular studies on Babesia, Theileria and Hepatozoon in southern Europe. Part II. Phylogenetic analysis and evolutionary history. Veterinary Parasitology, 114, 173-194.

11. d'Oliveira C, Van der Weide M, Habela MA, Jacquiet P, Jongejan F. 1995. Detection of Theileria annulata in blood samples of carrier cattle by PCR. Journal of Clinical Microbiology, 33, 2665-2669.

12. Darghouth MA. 2004. Piroplasmids of livestock in Tunisia. Archives de 1'Institut Pasteur Tunis, 81, 21-25.

13. Dean AG, Arner TG, Sunki GG, Friedman R, Lantinga M, Sangam S, Zubieta JC, Sullivan KM, Brendel KA, Gao Z, Fontaine N, Shu M, Fuller G, Smith DC, Nitschke DA, Fagan RF. 2011. Epi $\mathrm{Info}^{\mathrm{TM}}$, a database and statistics program for public health professionals. CDC: Atlanta, USA.

14. Durrani S, Khan Z, Khattak RM, Ali M, Hameed H, Taqddas A, Faryal M, Kiran S, Riaz M, Sajid M, Sheikh RS, Ali M, Iqbal F. 2012. A comparison of the presence of Theileria ovis by PCR amplification of their ssu rRNA gene in small ruminants from two provinces of Pakistan. Asian Pacific Journal of Tropical Diseases, 2, 43-47.

15. FAO. 2010. http://faostat.fao.org (accessed in November 2013).

16. Felsenstein J. 1985. Confidence limits on phylogenies: an approach using the bootstrap. Evolution, 39, 783-791.

17. Friedhoff KT. 1997. Tick-borne diseases of sheep and goats caused by Babesia, Theileria or Anaplasma spp. Parassitologia, 39, 99-109.

18. Gebrekidan H, Hailu A, Kassahun A, Rohousová I, Maia C, Talmi-Frank D, Warburg A, Baneth G. 2014. Theileria infection 
in domestic ruminants in northern Ethiopia. Veterinary Parasitology, 200, 31-38.

19. Gharbi M, Zribi L, Jedidi M, Chakkhari H, Hamdi S, R'hayem S, Zribi N, Souli M, Darghouth MA. 2013. Prévalence d'infection des ovins par Toxoplasma gondii en Tunisie. Bulletin de la Société de Pathologie Exotique, 106, 184-187.

20. Gubbels JM, de Vos AP, Van der Weide M, Viseras J, Schouls LM, de Vries E, Jongejan F. 1999. Simultaneous detection of bovine Theileria and Babesia species by reverse line blot hybridisation. Journal of Clinical Microbiology, 37, 1782-1789.

21. Heidarpour Bami M, Haddadzadeh HR, Kazemi B, Khazraiinia P, Bandehpour M, Aktas M. 2009. Molecular identification of ovine Theileria species by a new PCR-RFLP method. Veterinary Parasitology, 161, 171-177.

22. İnci A, İca A, Yildirim A, Duzlu OT. 2010. Identification of Babesia and Theileria species in small ruminants in Central Anatolia (Turkey) via reverse line blotting. Turkish Journal of Veterinary and Animal Sciences, 34, 205-210.

23. Iqbal F, Fatima M, Shahnawaz S, Naeem M, Shaikh RS, Shaikh AS, Aktas M, Ali M. 2011. A Study on the determination of risk factors associated with babesiosis and prevalence of Babesia sp., by PCR amplification, in small ruminants from Southern Punjab (Pakistan). Parasite, 18, 229-234.

24. Iqbal F, Khattak RM, Ozubek S, Khan AU, Ali M, Sheikh RS, Aktas M. 2013. Application of the reverse line blot assay for the molecular detection of Theileria and Babesia sp. in small ruminants of Pakistan. Iranian Journal of Parasitology, 8, 289295.

25. Liu AH, Yin H, Guan GQ, Schnittger L, Liu ZJ, Ma ML, Dang ZS, Liu JL, Ren QY, Bai Q, Ahmed JS, Luo JX. 2007. At least two genetically distinct large Babesia species infective to sheep and goats in China. Veterinary Parasitology, 147, 246-251.

26. M'ghirbi Y, Ros-García A, Iribar P, Rhaim A, Hurtado A, Bouattour A. 2013. A molecular study of tick-borne haemoprotozoan parasites (Theileria and Babesia) in small ruminants in Northern Tunisia. Veterinary Parasitology, 198, 72-77.

27. Mehlhorn H, Schein E, Ahmed JS. 1994. Theileria, in Kreier JP, Editor. Parasitic protozoa, vol. 7, Academic Press: San Diego, USA.

28. Najari S, Gaddour A, Abdennebi M, Ouni M. 2007. Specificities of the local kid's genotypes expression towards arid conditions in Southern Tunisia. Journal of Applied Science, 3, 301-306.

29. Papadopoulos B, Brossard M, Perie NM. 1996. Piroplasms of domestic animals in Macedonia of Greece. 3. Piroplasms of small ruminants. Veterinary Parasitology, 63, 67-74.

30. Ranjbar-Bahadori S, Eckert B, Omidian Z, Shirazi NS, Shayan P. 2012. Babesia ovis as the main causative agent of sheep babesiosis in Iran. Parasitology Research, 110, 1531-1536.

31. Razmi GR, Naghibi A, Aslani MR, Fathivand M, Dastjerdi K. 2002. An epidemiological study on ovine babesiosis in the
Mashhad suburb area, province of Khorasan, Iran. Veterinary Parasitology, 108, 109-115.

32. Razmi GR, Naghibi A, Aslani MR, Dastjerdi K, Hossieni H. 2003. An epidemiological study on Babesia infection in small ruminants in Mashhad suburb, Khorasan province, Iran. Small Ruminant Research, 50, 39-44.

33. Rekik M, Aloulou R, Ben Hamouda M. 2005. Small ruminant breeds of Tunisia, in Iñíguez $\mathrm{L}$, Editor. Characterisation of small ruminant breeds in West Asia and North Africa, vol. 2, North Africa, International Centre for Agricultural Research in the Dry Areas (ICARDA): Amman, Jordan.

34. Saitou N, Nei M. 1987. The neighbour-joining method: a new method for reconstructing phylogenetic trees. Molecular Biology and Evolution, 4, 406-425.

35. Schnittger L, Yin H, Gubbels MJ, Beyer D, Niemann S, Jongejan F, Ahmed JS. 2003. Phylogeny of sheep and goat Theileria and Babesia parasites. Parasitology Research, 91, 398-406.

36. Schnittger L, Yin H, Qi B, Gubbels MJ, Beyer D, Nieman S, Jongejan F, Ahmed JS. 2004. Simultaneous detection and differentiation of Theileria and Babesia parasites infecting small ruminants by reverse line blotting. Parasitology Research, 92, 189-196.

37. Schwartz D. 1993. Méthodes statistiques à l'usage des médecins et des biologistes. 3ème éd. Flammarion: Paris, France.

38. Tamura K, Nei M. 1993. Estimation of the number of nucleotide substitutions in the control region of mitochondrial DNA in humans and chimpanzees. Molecular Biology and Evolution, $10,512-526$.

39. Tamura K, Peterson D, Peterson N, Stecher G, Nei M, Kumar S. 2011. MEGA5: molecular evolutionary genetics analysis using maximum likelihood, evolutionary distance, and maximum parsimony methods. Molecular Biology and Evolution, 28, 2731-2739.

40. Toma B, Dufour B, Sanaa M, Bénet JJ. 2007. Épidémiologie appliquée à la lutte collective contre les maladies animales transmissibles majeures. 2ème éd., Association pour l'étude de l'épidémiologie des maladies animales: Paris, France.

41. Uilenberg G. 2001. Babesiosis, in Service MW, Editor. Encyclopaedia of arthropod-transmitted infections of man and domesticated animals. CABI: Wallingford, UK.

42. Walker AR, Bouattour A, Camicas J-L, Estrada-Peña A, Horak IG, Latif AA, Pegram RG, Preston PM. 2003. Ticks of domestic animals in Africa. ED. Bioscience Reports: Edinburgh, UK.

43. Zaeemi M, Haddadzadeh HR, Khazraiinia P, Kazemi B, Bandehpour M. 2011. Identification of different Theileria species (Theileria lestoquardi, Theileria ovis, and Theileria annulata) in naturally infected sheep using nested PCR-RFLP. Parasitology Research, 108, 837-843.

Cite this article as: Rjeibi MR, Gharbi M, Mhadhbi M, Mabrouk W, Ayari B, Nasfi I, Jedidi M, Sassi L, Rekik M \& Darghouth MA: Prevalence of piroplasms in small ruminants in North-West Tunisia and the first genetic characterisation of Babesia ovis in Africa. Parasite, 2014, 21, 23. 
Reviews, articles and short notes may be submitted. Fields include, but are not limited to: general, medical and veterinary parasitology; morphology, including ultrastructure; parasite systematics, including entomology, acarology, helminthology and protistology, and molecular analyses; molecular biology and biochemistry; immunology of parasitic diseases; host-parasite relationships; ecology and life history of parasites; epidemiology; therapeutics; new diagnostic tools.

All papers in Parasite are published in English. Manuscripts should have a broad interest and must not have been published or submitted elsewhere. No limit is imposed on the length of manuscripts.

Parasite (open-access) continues Parasite (print and online editions, 1994-2012) and Annales de Parasitologie Humaine et Comparée (1923-1993) and is the official journal of the Société Française de Parasitologie. 